\title{
Foraminiferal zonation of a boring in Quaternary deposits of the northern North Sea
}

\author{
ROLF W. FEYLING-HANSSEN
}

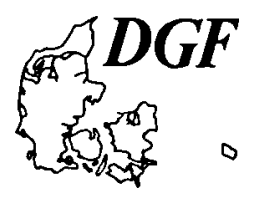

Feyling-Hanssen, R. W.: Foraminiferal zonation of a boring in Quaternary deposits of the northern North Sea. Bull. geol. Soc. Denmark, vol 31, pp. 29-47. Copenhagen, November 15th, 1982. https://doi.org/10.37570/bgsd-1982-31-03

The foraminiferal content of samples from a $122 \mathrm{~m}$ deep borehole in the Statfjord Field of the northern North Sea permitted a biostratigraphical subdivision of the sequence into 11 units. The paleoecology of these units is discussed. Most of them reflect High-Arctic ice age conditions, whereas two of them are of interstadial character. Distinctly ameliorated assemblages occur $20 \mathrm{~m}$ below sea floor. They correlate with late Statfjord Interglacial assemblages from a previously described boring and probably originate from the end of the Eemian. An attempt has been made to correlate the units of the present boring with published deep sea oxygen isotope stages.

R. W. Feyling-Hanssen, Department of Micropaleontology, Institute of Geology, University of Aarhus, 8000 Arhus C, Denmark. May 3rd, 1982.

The present investigation deals with borehole 3506 in the Statfjord B Field of the Norwegian sector of the northern North Sea. Core samples were provided by the Norwegian Geotechnical Institute, Oslo. The bore site is on a plateau to the west of the Norwegian Channel in $145 \mathrm{~m}$ of water. Its latitude is $61^{\circ} 12.4^{\prime} \mathrm{N}$, longitude $1^{\circ} 50^{\prime} \mathrm{E}$.

The foraminiferal content of thirtynine sediment samples from this boring was investigated.

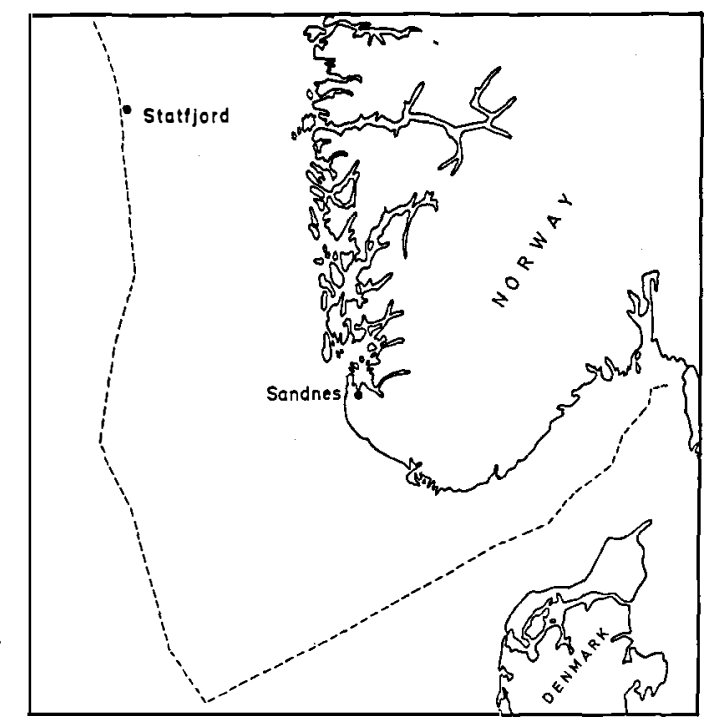

Fig. 1. Location of the investigated boring.
The uppermost sample, $1 \mathrm{~A}$, is from the present sea bed, the deepest sample, no. 27, from $122 \mathrm{~m}$ below the sea bed.

Most of the samples were quite rich in foraminifera, the richest one, no. $6 \mathrm{C}$ at $5.5 \mathrm{~m}$, contained 25,000 specimens in $100 \mathrm{~g}$ sediment. The deepest samples, from no. 23, at $106.4 \mathrm{~m}$ down, were barren or nearly barren.

The foraminiferal species in the investigated samples show that the whole sequence is of Quaternary age. Most specimens are in a good state of preservation, suggesting that they lived and died and were buried at the bore site. Some samples contained reworked, worn, foraminifera of Upper Cretaceous age in addition to the Quaternary specimens.

The samples were processed and analyzed in accordance with previously described procedures (Feyling-Hanssen, 1958, 1964, 1981, 1982; Feyling-Hanssen et al., 1971). In addition to the paleoecological parameters previously used, viz., $\%$ of boreal benthonic specimens, $\%$ of planktonic specimens, faunal deversity (Walton, 1964), faunal dominance, number of benthonic specimens per $100 \mathrm{~g}$ sediment, and number of benthonic species per sample, a \% of Shallowwater specimens is also included (Feyling-Hanssen, 1982).

The counted foraminiferal assemblages are housed in the Department of Micropaleontology, Geological Institute, Aarhus University. 


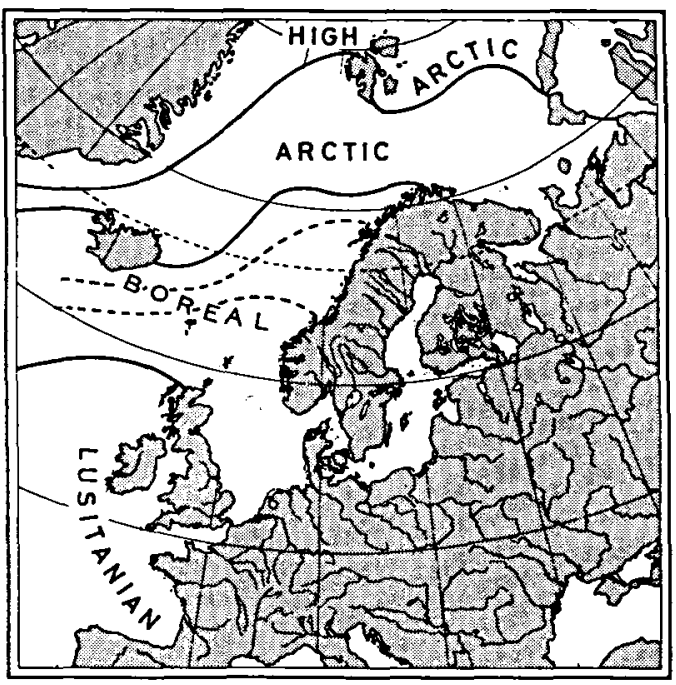

Fig. 2. Zoogeographical division used in grouping the foraminifera (Redrawn from Feyling-Hanssen, 1955).

\section{Sediment}

The sediments of Borehole 3506 were analysed by Tor Løken of the Norwegian Geotechnical Institute, Oslo. His description (written communication, 1977) was as follows:

" $0-0.2 \mathrm{~m}$, top layer: Consists of sand and gravel with numerous fragments of molluscan shells. $0.2-9.0 \mathrm{~m}$ : stiff, silty and homogenous clay. 9.0-10.0 m: Sandy clay.

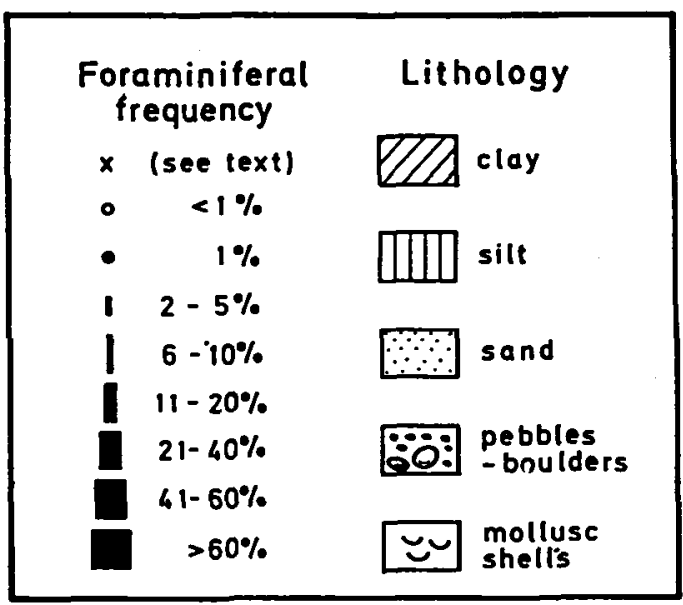

Fig. 3. Symbols used in the range charts and diagrams. $X$ indicates specimen observed only in the uncounted part of the sample.
10.0-20.0 m: very fine sand with isolated shell fragments and a little gravel.

20.0-27.0 m: stiff, sandy clay with some granules and stones.

27-32 m: silty to clayey sand.

$32-45 \mathrm{~m}$ : silty clay.

$45-58 \mathrm{~m}$ : fine to silty sand.

58-102 m: clay.

102-122 m: fine to medium sand".

Scattered particles of lignite occur at several levels. There is no glacigenic deposit among the investigated samples.

\section{Zonation}

The frequency destribution of 31 selected taxa of foraminifera is illustrated in the range chart of fig. 4a. The symbols used are explained in fig. 3 . Paleoecological parameters were calculated for each assemblage and are presented as diagrams in fig. 4b. All the data presented in figs. $4 a$ and $b$ have been combined in an attempt to distinguish between different paleoecological units of the boring. Eleven assemblage zones have thus been established. They are indicated by numbers from 11 , oldest, to 1 , youngest.

Zone 11 comprises the deepest samples of the boring from no. 27 , at $122.0 \mathrm{~m}$ below sea floor, to no. 23 , at $106.4 \mathrm{~m}$. These samples are barren or nearly barren of foraminifera. Only no. 25 , at $112.7 \mathrm{~m}$, contained 50 worn specimens including Elphidium excavatum (Terquem), Nonion orbiculare (Brady), Cibicides lobatulus (Walker and Jacob), Elphidium asklundi Brotzen and one specimen of Elphidiella hannai (Cushman and Grant). A single Globigerina pachyderma (Ehrenberg) occurred. Sample no. 27 contained 5 worn specimens of Elphidium excavatum. 3 worn Nonion orbiculare and 1 fragmented Cibicides lobatulus.

All these are considered reworked, and zone 11 is probably a non-marine deposit or a shallow-water deposit which has been exposed to subaerial leaching and dissolution of its original content of calcareous fossils.

Zone 10 (Table 1 ) represented by sample $22 \mathrm{~A}$ at $103.2 \mathrm{~m}$, is characterized by high frequency of Cibicides lobatulus (16\%) and a firm representa- 
Table 1, Zone 10

Sample no. 22A, Boring 3506A, depth $103.2 \mathrm{~m}$, weight $120 \mathrm{~g}$

\begin{tabular}{|c|c|}
\hline Species & Percentage \\
\hline 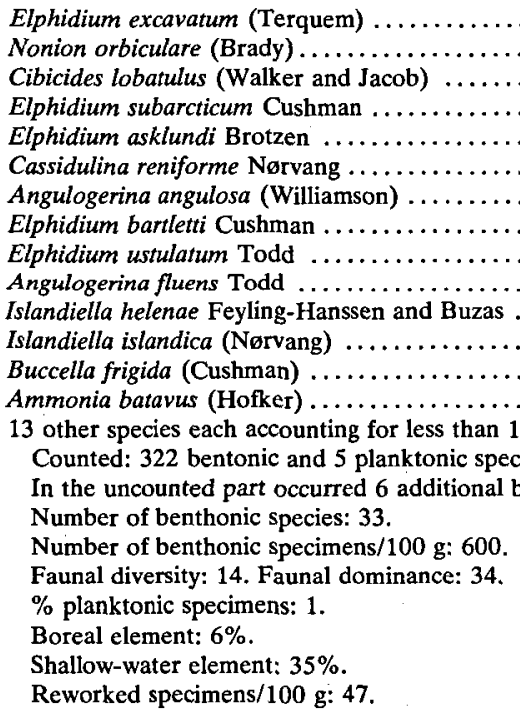 & $\begin{array}{r}34 \\
17 \\
16 \\
7 \\
7 \\
3 \\
2 \\
2 \\
2 \\
1 \\
1 \\
1 \\
1 \\
1\end{array}$ \\
\hline
\end{tabular}

tion of typical shallow-water species such as Nonion orbiculare $(17 \%)$, Elphidium subarcticum Cushman $(7.5 \%)$, E. asklundi $(7 \%)$, and E. bartletti Cushman (2\%). E. ustulatum Todd comprises $2.2 \%$. Shallow-water specimens account for $35.5 \%$.

The sediment of zone 10 was thus deposited in extremely shallow water. A marine transgression probably started at this level of the borehole. Many foraminifera of this sample have their last or latest chambers broken off, some of them are worn. As a whole the assemblage mirrors a high-energy environment.

The assemblage is Arctic but ameliorated; 6\% of the benthonic assemblage consist of Boreal foraminifera.

Zone 9 (Table 2) comprises the samples 20A, $21 \mathrm{~A}$ and $21 \mathrm{C}$, approximately between 90 and $100 \mathrm{~m}$ below sea floor. It represents a distinctly ameliorated interval. The content of boreal specimens is $11 \%$ in $21 \mathrm{C}, 16 \%$ in $21 \mathrm{~A}$, and again $11 \%$ in $20 \mathrm{~A}$. Bulimina gibba/marginata (comprising Bulimina marginata d'Orbigny, $B$. aculeata d'Orbigny, $B$. elongata d'Orbigny, $B$. gibba Fornasini) is firmly represented and so is Elphidium albiumbilicatum (Weiss). An- gulogerina angulosa (Williamson) is quite common.

The transgression which commenced in zone 10 continues through zone 9 . The content of shallow-water specimens decreases upwards from $23 \%$ in sample no. $21 \mathrm{C}$ to $21 \%$ in $21 \mathrm{~A}$ to $18 \%$ in $20 \mathrm{~A}$, but still the water must have been relatively shallow. Most probably because of this shallow water the faunal diversity and the number of different species remains low (diversity about 10 , number of species 20 ). There is an increase in the number of benthonic specimens per $100 \mathrm{~g}$ sediment from 650 in $21 \mathrm{C}$ to 2100 in $20 \mathrm{~A}$.

Zone 8 (Table 3 ) is represented only by sample no. $19 \mathrm{~A}$ at $87.2 \mathrm{~m}$. This sample carries so much lignite and other plant debris that it looks dark brown when washed. Large quantities of Prequaternary foraminifera are also present (1340 specimens $/ 100 \mathrm{~g}$ sediment), almost as many as Quaternary specimens (1540/100 g). One might suspect the entire assemblage to be reworked, but this is unlikely because the Quaternary specimens are very well preserved, showing little if any damage.

The Quaternary assemblage of this sample is 


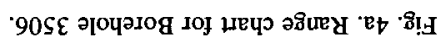

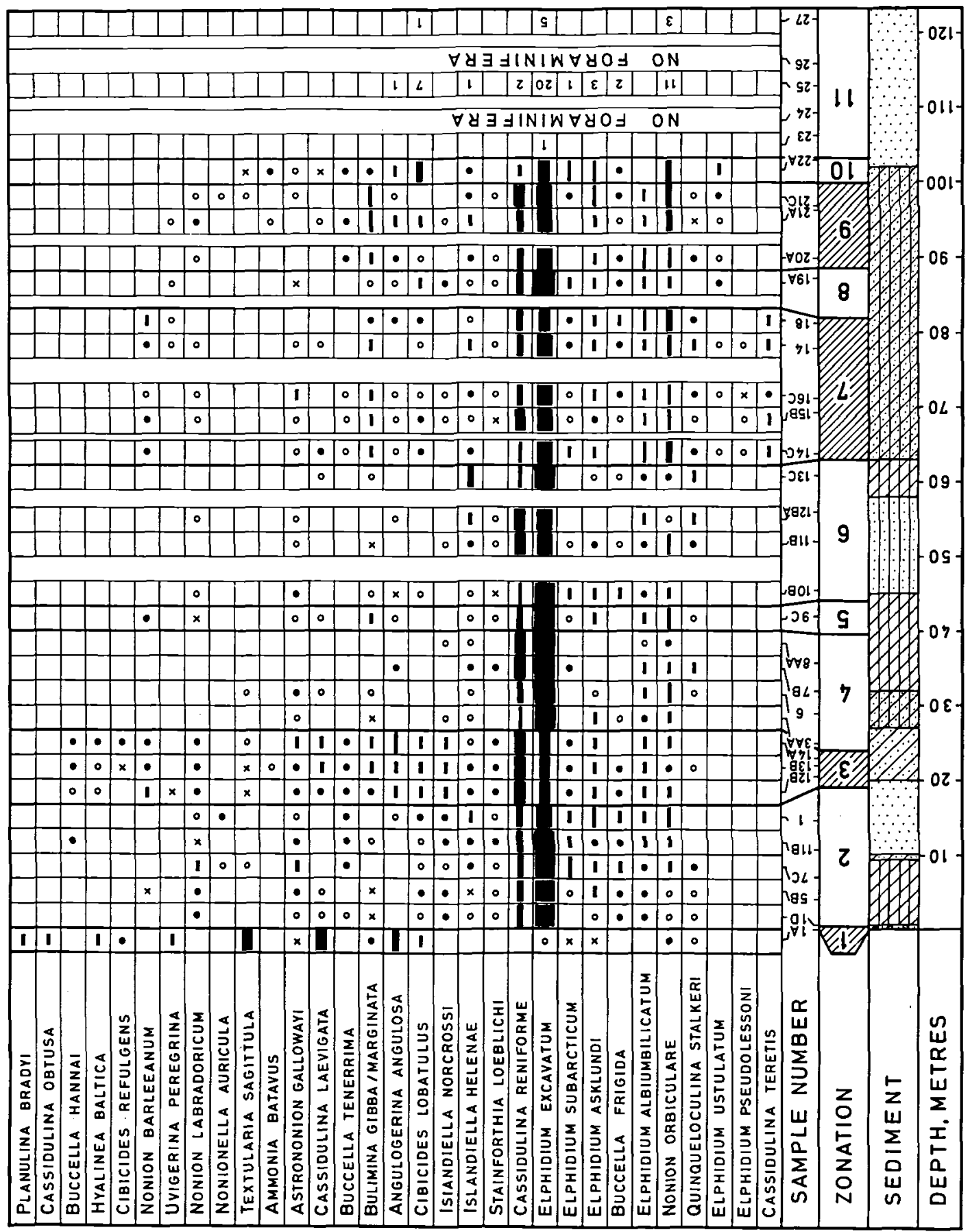




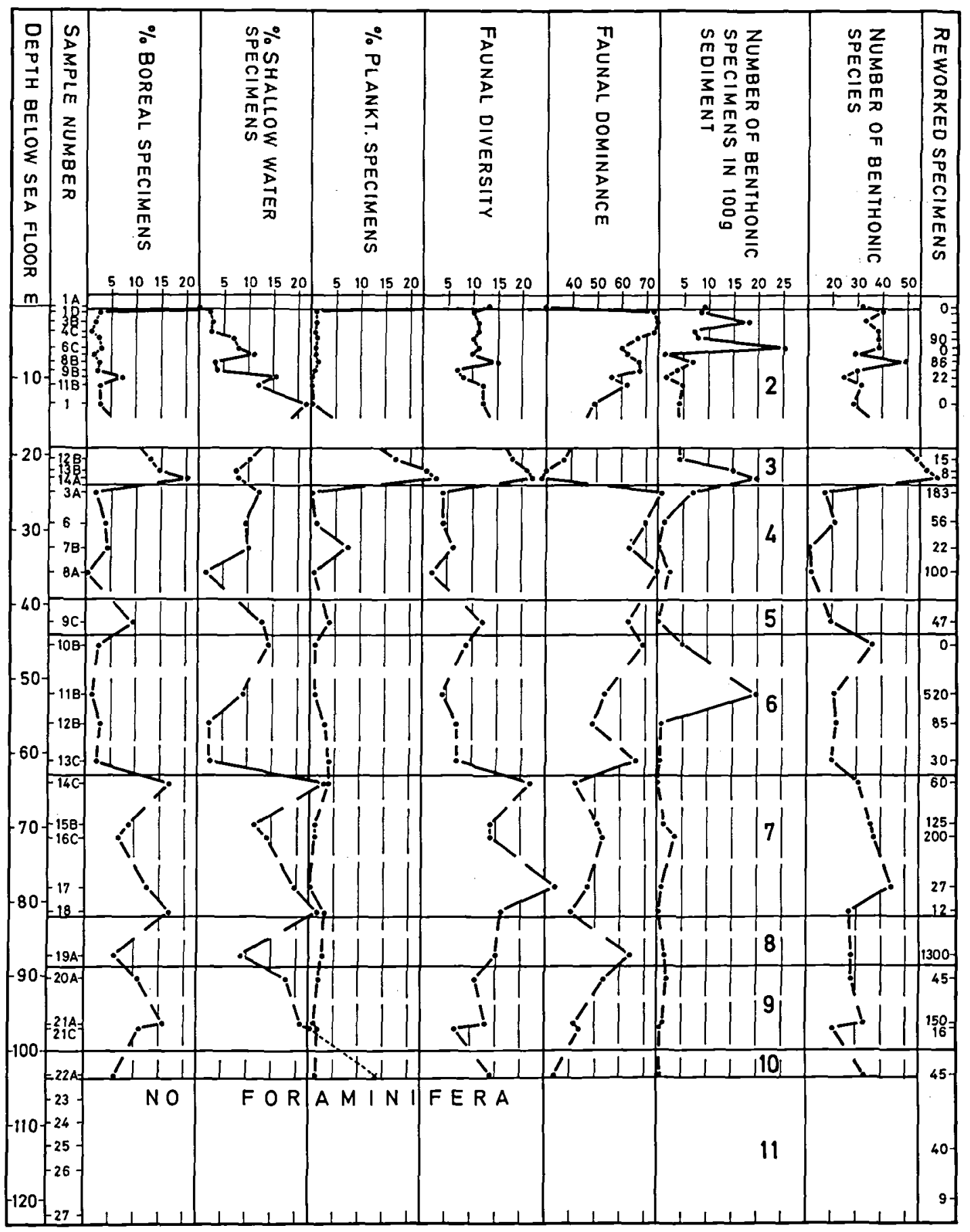

Fig. 4b. Diagrams for Borehole 3506. 
Table 2, Zone 9

Sample no. 21 A, Boring 3506A, depth $96.6 \mathrm{~m}$, weight $160 \mathrm{~g}$

\begin{tabular}{|c|c|}
\hline Species & Percentage \\
\hline 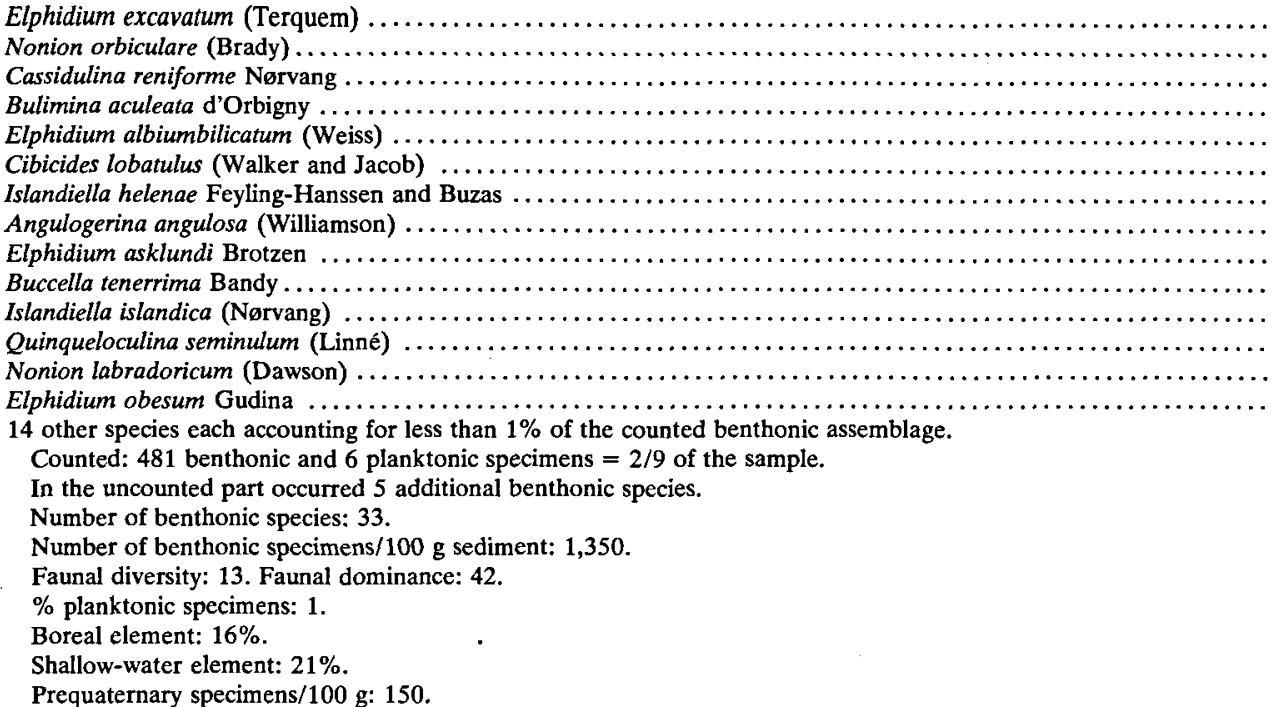 & $\begin{array}{r}42 \\
14 \\
13 \\
8 \\
4 \\
3 \\
2 \\
2 \\
2 \\
1 \\
1 \\
1 \\
1 \\
1\end{array}$ \\
\hline
\end{tabular}

considered a zone in its own right because it reflects a quite marked climatic deterioration in comparison with the underlying zone. The boreal element makes up only $6 \%$ of the fauna and the faunal dominance (Elphidium excavatum clavata Cushman) is 64. Water depths seem to have in- creased further, as the shallow-water specimens make up only $8.8 \%$ whereas planktonic foraminifera account for $4.6 \%$ of the total assemblage of benthonic + planktonic specimens.

A cold spell is indicated by the assemblage of zone 8 .

Table 3, Zone 8

Sample no. 19A, depth $87.2 \mathrm{~m}$, weight $130 \mathrm{~g}$

Species

Percentage

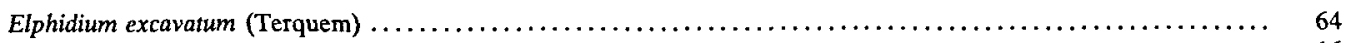

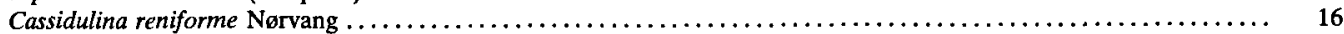

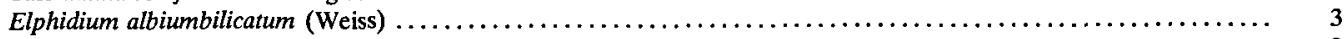

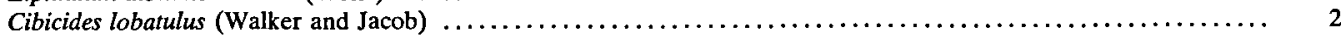

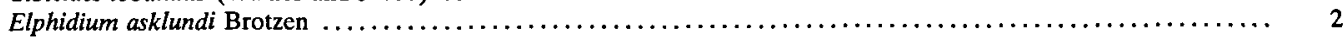

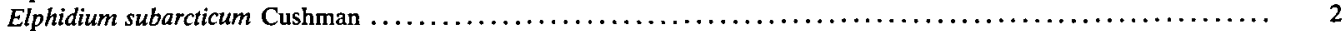

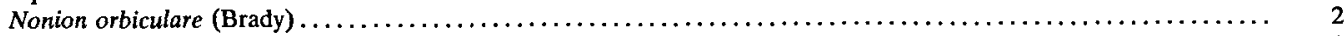

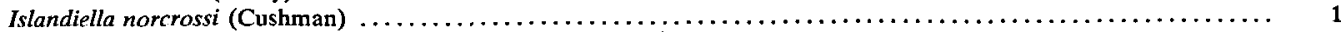

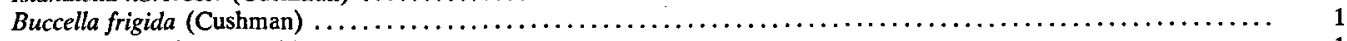

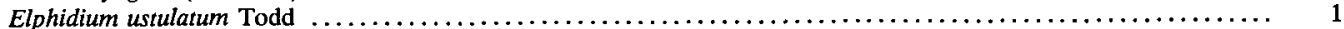

16 other species each accounting for less than $1 \%$ of the counted assemblage.

Counted: 250 benthonic and 12 planktonic specimens $=1 / 8$ of the sample.

Two additional species were observed in the uncounted part.

Number of benthonic species: 28 .

Number of benthonic specimens $/ 100 \mathrm{~g}$ sediment: 1,550 .

Faunal diversity: 15. Faunal dominance: 64 .

$\%$ planktonic specimens: 5 .

Boreal element: $5 \%$.

Shallow-water element: $9 \%$.

Reworked specimens/100 g: 1,350 . 
Table 4, Zone 7

Sample no. 14C, depth $63.9 \mathrm{~m}$, weight $100 \mathrm{~g}$

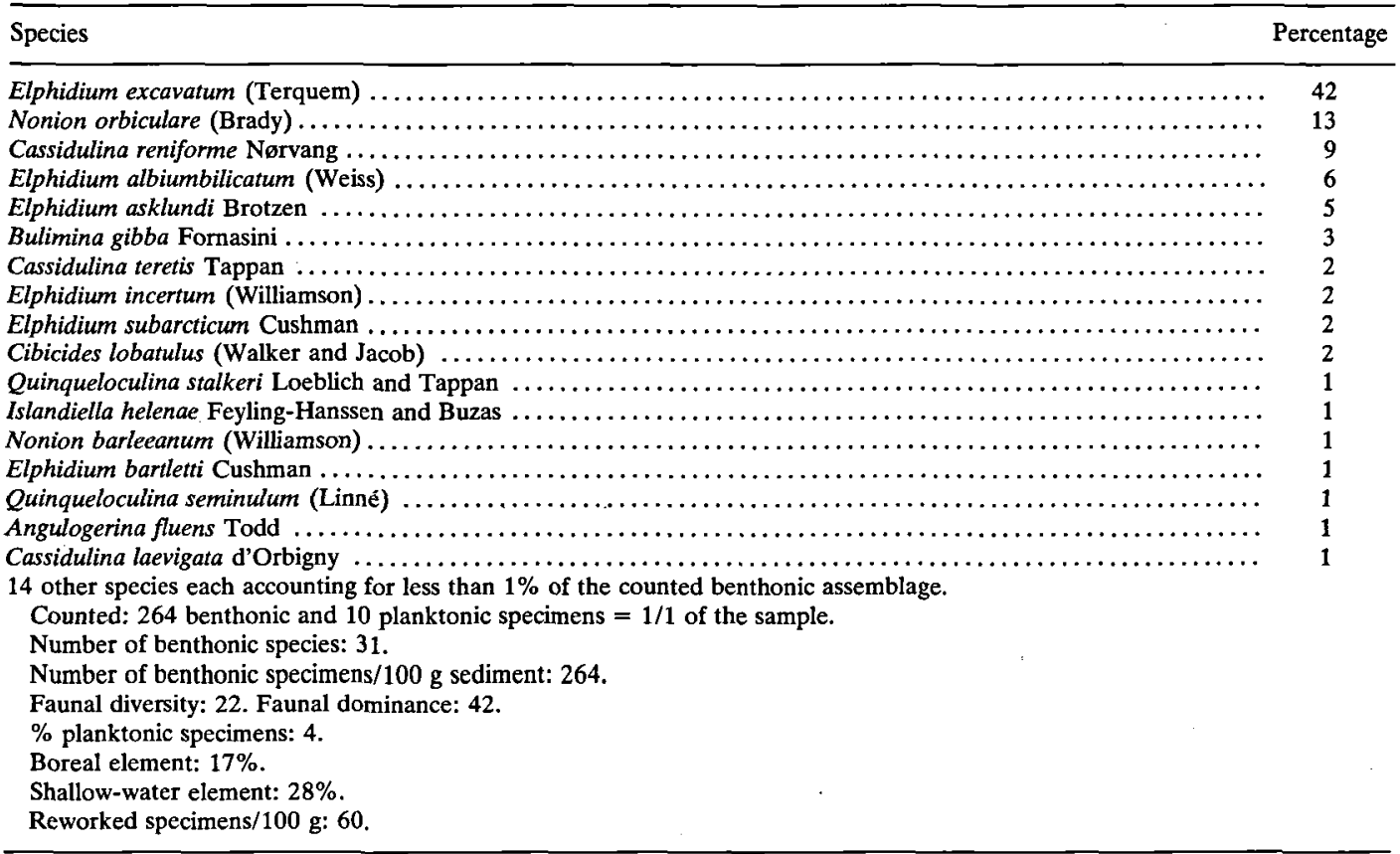

Zone 7 (Table 4) is represented by the samples $18,17,16 \mathrm{C}, 15 \mathrm{~B}$ and $14 \mathrm{C}$ covering the borehole interval from $82 \mathrm{~m}$ to $63 \mathrm{~m}$. These samples contain distinctly ameliorated assemblages, their content of boreal foraminifera ranges from $9 \%$ to $17 \%$. Among the boreal species are Bulimina gibba (large with triangular cross section), $A n$ gulogerina angulosa, Cassidulina laevigata d'Orbigny, Nonion barleeanum (Williamson) and Elphidium albiumbilicatum. Uvigerina peregrina Cushman occurs in the two lowermost samples of the zone.

Elphidium excavatum still dominates the assemblages and Cassidulina reniforme Nørvang is subdominant in most of them - as often found with Arctic assemblages of the present day. But this dominance is moderate (less than $\mathbf{5 0}$ in three of the samples) and the faunal diversity is remarkably high, amounting to 22 in sample $14 \mathrm{C}$ and even to 27 in sample 17 (average 20 for the zone).

The content of shallow-water specimens ranges from $12 \%$ in sample $15 \mathrm{~B}$ to $28 \%$ in sample $14 \mathrm{C}$, the average for the zone being $21 \%$. Very few planktonic foraminifera occur. Only in the up- permost sample of the zone do they make up nearly $4 \%$, in the other samples they are fewer. The water into which the sediments of zone 7 were deposited was shallow, probably less than $20 \mathrm{~m}$ deep. The salinity was probably close to normal marine.

A charateristic feature of zone 7 is a quite common occurrence of Cassidulina teretis Tappan (cf. Feyling-Hanssen and Buzas, 1976; Feyling-Hanssen, 1980) in all the samples. This species does not occur in any other unit of the borehole. A few, probably reworked specimens of Elphidiella hannai (Cushman and Grant) and Cibicides grossa Ten Dam and Reinhold, occurred in zone 7 . These may have been derived from Lower Pleistocene and Upper Tertiary deposits nearby.

Zone 7 represents a mild interval with interstadial or close to interglacial conditions. A decrease in species number from 44 in sample 17 to 31 in sample $14 \mathrm{C}$ may signal the approach of more severe climatic ages.

Zone 6 (Table 5) comprizes the samples 13C, $12 \mathrm{BA}, 11 \mathrm{~B}$ and 10B. Its boundaries have been 
Table 5, Zone 6

Sample no. 13C, depth $61.1 \mathrm{~m}$, weight $140 \mathrm{~g}$

\begin{tabular}{|c|c|c|}
\hline \multicolumn{2}{|l|}{ Species } & Percentage \\
\hline 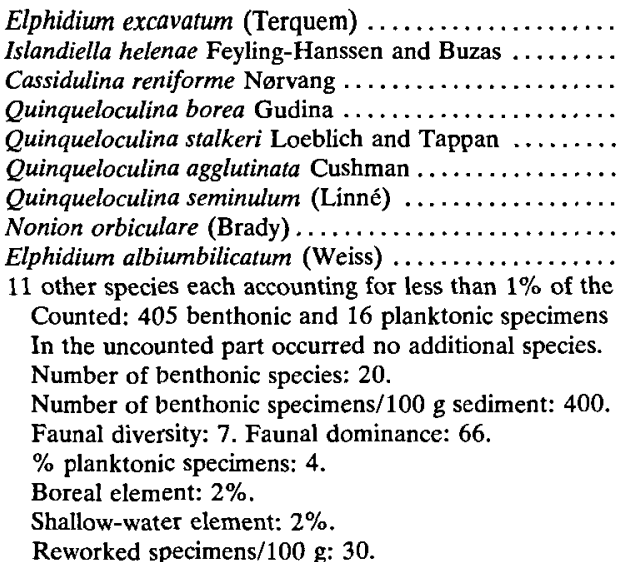 & 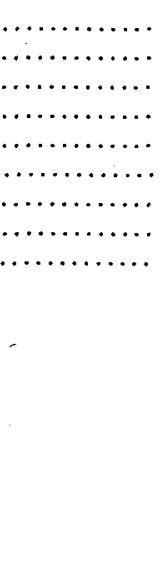 & $\begin{array}{r}66 \\
12 \\
10 \\
3 \\
3 \\
1 \\
1 \\
1 \\
1\end{array}$ \\
\hline
\end{tabular}

placed at $63 \mathrm{~m}$ and $44 \mathrm{~m}$ below sea floor. The assemblages are High-Arctic with a dominance of Elphidium excavatum clavata and with Cassidulina reniforme second in frequency. The faunal diversity has dropped to between 4 and 9 and the content of boreal specimens to between $0.9 \%$ and $2.8 \%$. There are only $20-22$ different species per sample in the lower half of the zone rising to 36 in the uppermost sample.

Zone 6 thus represents a stadial of an ice age.

There is a sudden drop in the content of shallow-water specimens from zone 7 to zone 6 . Sample 13C and 12B in the lower half of zone 6 contain only $2.4 \%$ and $2.3 \%$ respectively. This would mean a marked deepening from zone 7 to zone 6 . The content of shallow-water specimens again increases in the upper half of the zone to $9 \%$ in sample $11 \mathrm{~B}$ and $14 \%$ in $10 \mathrm{~B}$. At the same time planktonic specimens have practically disappeared, $0.8 \%$ in $11 \mathrm{~B}$ and $0.9 \%$ in $10 \mathrm{~B}$. A regression is thus indicated in the upper half of zone 6.

Large, glistening specimens of the Arctic species Islandiella helenae Feyling-Hanssen and Buzas are frequent in the lowest sample of the zone $(12 \%)$. They decrease in frequency with the shallower conditions upwards in the zone.

Sample $11 B$ at $52.0 \mathrm{~m}$ contained 20,000 benthonic foraminifera per $100 \mathrm{~g}$ sediment. The overlying sample $10 \mathrm{~B}$ had $5,000 / 100 \mathrm{~g}$ but the two lower samples, $13 \mathrm{C}$ and $12 \mathrm{~B}$ contained only 400 and 650 specimens per $100 \mathrm{~g}$ sediment respectively.

Fragments of the Arctic mollusc species Yoldiella lenticula (Müller) and Nuculana pernula (Müller) occurred in sample $13 \mathrm{C}$ at $61.1 \mathrm{~m}$.

Zone 5 (Table 6) is represented only by sample $9 \mathrm{C}$ at $42.2 \mathrm{~m}$. Elphidium excavatum dominates with Cassidulina reniforme second in abundance. The assemblage is distinguished as a unit of its own because its percentage of boreal specimens is as high as 9.5. Compared to the assemblage below as well as to the one above this makes a marked difference. There is also an increase in diversity and a slight drop in dominance.

The assemblage is poor, but it may signal an interstadial which may have lasted longer than it looks from the poor representation of only one sample; there is an unsampled interval of $6.6 \mathrm{~m}$ between sample $9 \mathrm{C}$ and $8 \mathrm{~A}$ above.

Many particles of lignite occurred, but the Quaternary foraminifera are in a good state of preservation.

Zone 4 (Table 7) is represented by the samples $8 \mathrm{AA}, 7 \mathrm{~B}, 6$, and $3 \mathrm{AA}$. The zone boundaries have been placed at $39 \mathrm{~m}$ and $24 \mathrm{~m}$. The assemblages of this zone reflect High-Arctic, extremely severe environmental conditions. There is a pronounced 
Table 6, Zone 5

Sample no. 9C, depth $42.2 \mathrm{~m}$, weight $100 \mathrm{~g}$

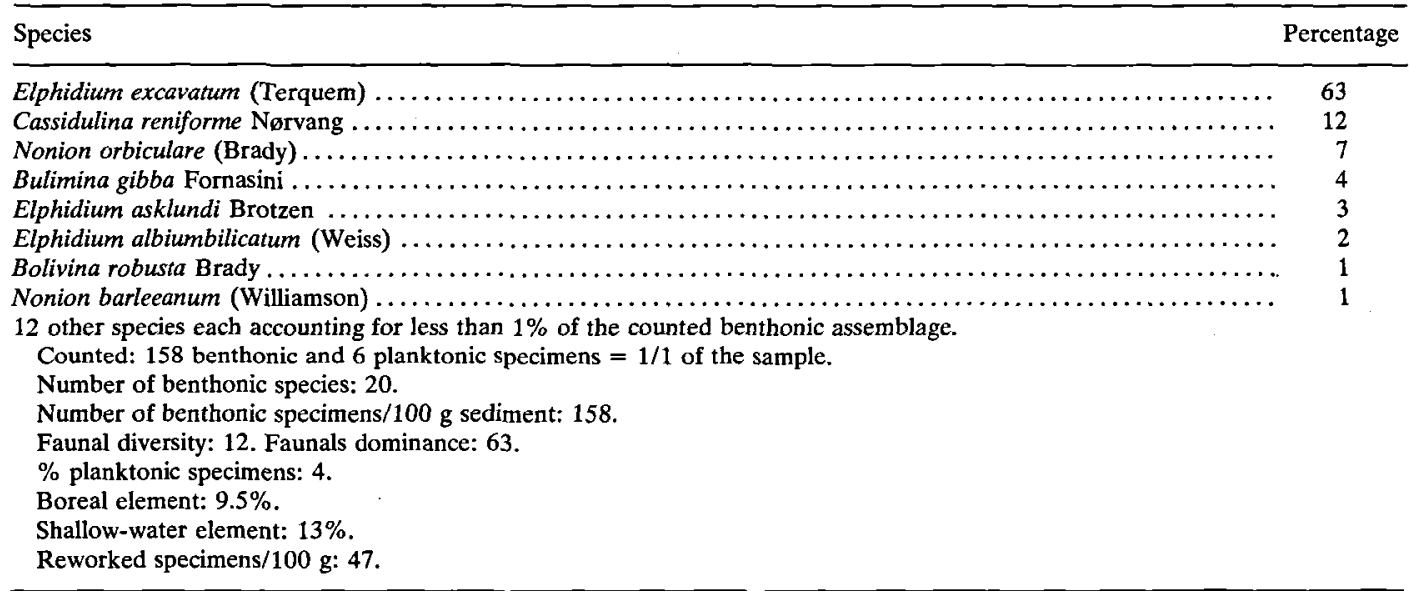

dominance of Elphidium excavatum clavata; it accounts for $75 \%$ of the benthonic assemblage of sample $8 \mathrm{AA}, 63 \%$ in $7 \mathrm{~B}, 70 \%$ in 6 , and $76 \%$ in sample $3 \mathrm{AA}$. The faunal diversity is less than 5 in three of the samples 6 in the fourth (7B), these parameters thus indicate an extremely high environmental stress. Accordingly the number of species per sample varies from 11 to 17 . The content of boreal specimens ranges from $0.3 \%$ to $4.0 \%$ (average $2.4 \%$ ).

Many specimens of Elphidium excavatum clavata are remarkably small and flat. If a connection between depauperation of Elphidium excavatum and salinity is assumed (e.g. FeylingHanssen, 1964, p.187), the salinity of the water into which zone 4 was deposited was probably less than full marine. There is about $10 \%$ shallow-water specimens in the upper three samples indicating moderate depth. The content of planktonic specimens is low except in sample 7B where they attain $7 \%$. This sample is, however extremely poor in foraminifera, containing only 100 benthonic and 8 planktonic specimens in 100 g.

Zone 4 probably represents a stadial of an ice age.

Zone 3 (Table 8 ) is represented by the samples $14 \mathrm{~A}, 13 \mathrm{~B}$ and 12B. Its boundaries are placed at $24 \mathrm{~m}$ and $19.7 \mathrm{~m}$. A pronounced amelioration of marine climatic conditions is reflected by the foraminiferal assemblages of these samples - and

Table 7, Zone 4

Sample no. 8AA, depth $35.6 \mathrm{~m}$, weight $90 \mathrm{~g}$

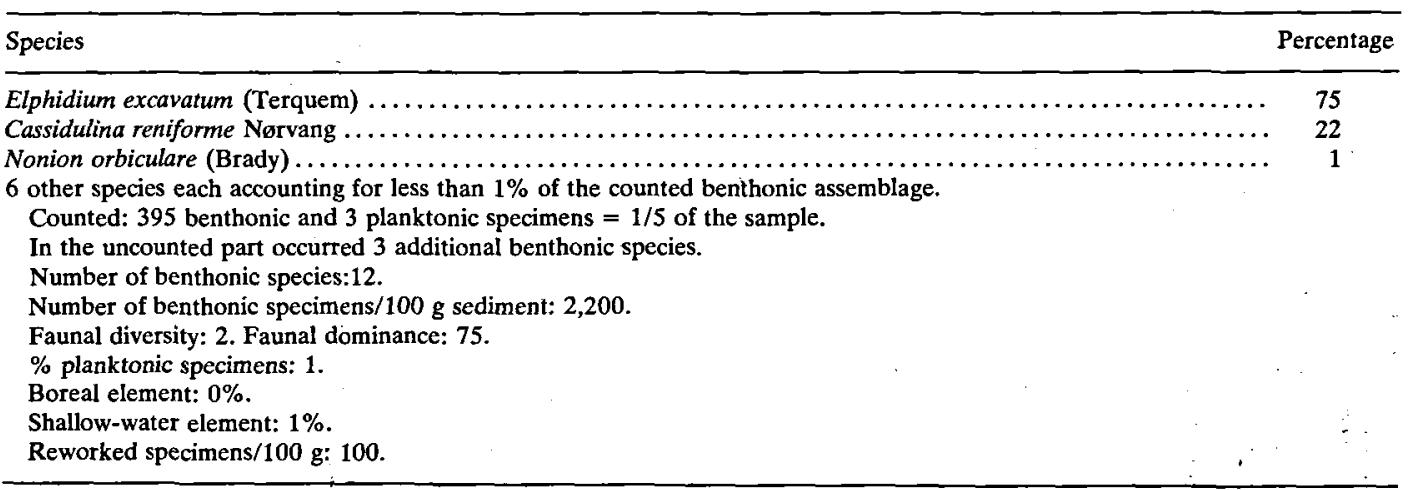


Table 8, Zone 3

Sample no. 14A, depth $23.0 \mathrm{~m}$, weight $70 \mathrm{~g}$

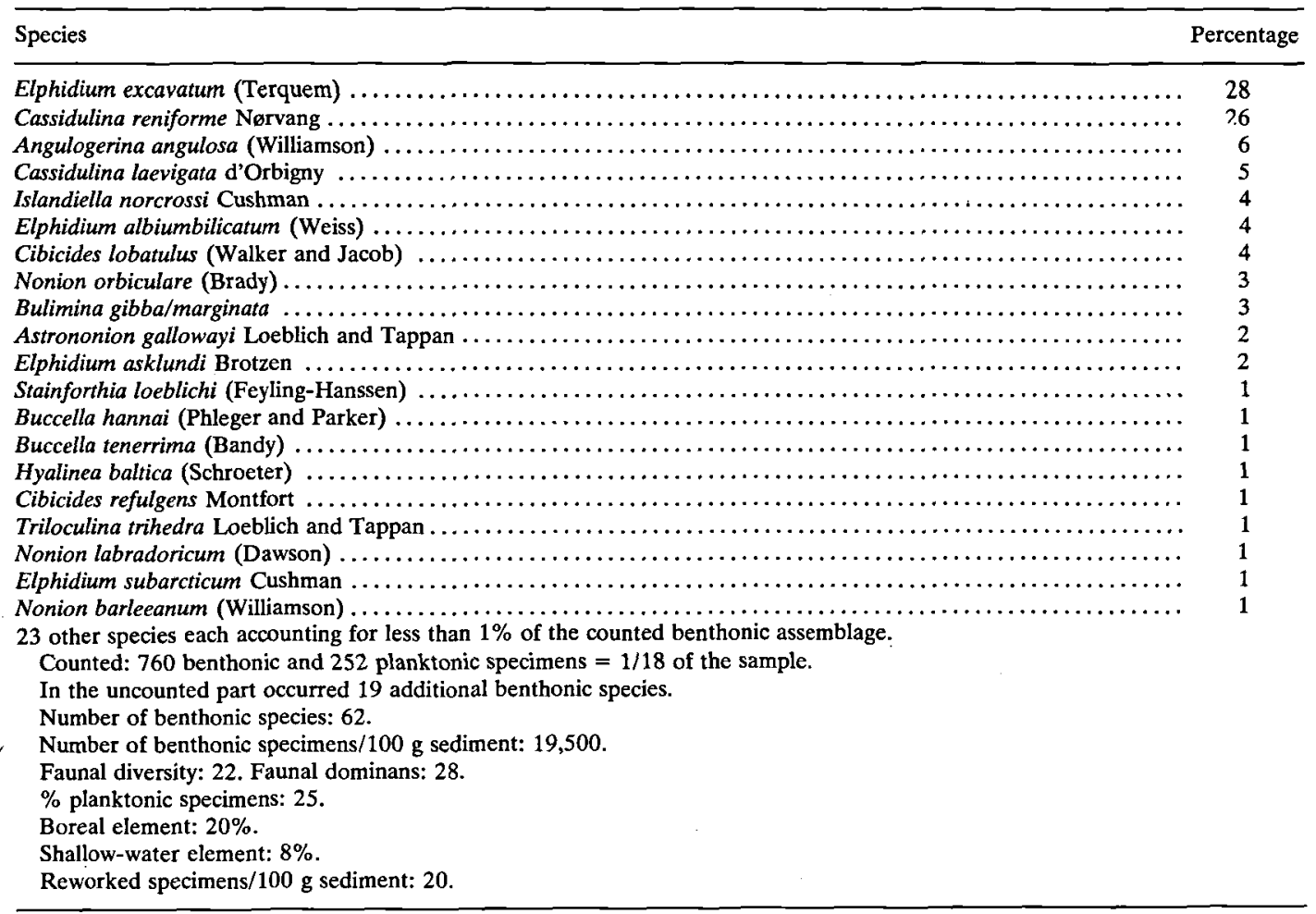

at the same time a distinct climatic deterioration upwards through this unit. Boreal foraminifera account for $20 \%$ of the benthonic assemblage in sample $14 \mathrm{~A}, 15 \%$ in $13 \mathrm{~B}$, and $13 \%$ in $12 \mathrm{~B}$. There are 62 different benthonic species in 14A, 58 in 13B, and 54 in the uppermost sample of the zone, 12B.

Characteristic boreal species of zone 3 are (cf. Table 3) Angulogerina angulosa, Cassidulina laevigata, Bulimina gibba/marginata and $\mathrm{El}$ phidium albiumbilicatum. Less frequent are Cibicides refulgens Montfort, Hyalinea baltica Schroeter and Nonion barleeanum (Williamson).

Islandiella norcrossi (Cushman) becomes frequent with this zone. Another frequent species is Cibicides lobatulus, represented by quite large specimens. Astrononion gallowayi is consistently present.

Faunal deversity is very high, from 22 to 18 , whilst faunal dominance is remarkably low, from 28 to 37 . This is indicative of favourable conditions for foraminiferal life.
A regression took place through the zone. Planktonic specimens make up $25 \%$ of the total assemblage in the lowest sample, $23 \%$ in the middle, and $17 \%$ in the upper sample. Except for the top sample of the boring, with its $63 \%$, these are the highest percentages of planktonic foraminifera found in any of the investigated samples of the present boring. This infers a relatively free connection with an open ocean during deposition of zone 3 . This suggests that a considerable water depth must have existed, probably in excess of $70 \mathrm{~m}$.

Zone 3 represents the end of an interglacial. A significant number of boreal species is still present, but a larger number of colder water forms have already immigrated into the area.

The warmer, climax faunas of this interglacial are not recorded in the present boring. A hiatus is, therefore, suggested between zone 4 and zone 3.

Zone 2 (Table 9) is represented by 11 samples, 
Table 9, Zone 2

Sample no. $4 \mathrm{C}$, depth $3.2 \mathrm{~m}$, weight $150 \mathrm{~g}$

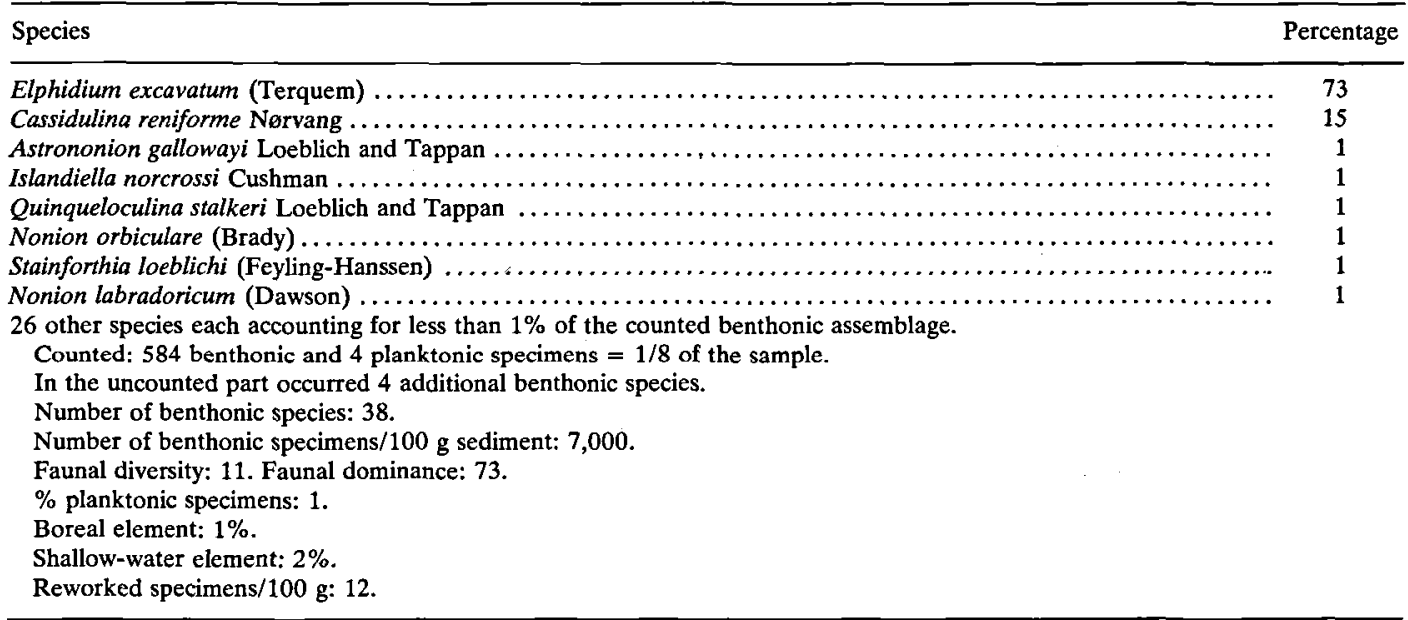

from no. 1 at $14.7 \mathrm{~m}$ to no. $1 \mathrm{D}$ at $0.5 \mathrm{~m}$. The zone boundaries have been placed at $19.7 \mathrm{~m}$ and 0.25 $\mathrm{m}$ below sea floor. The position of the lower boundary is uncertain because of an unsampled interval of approximately $6 \mathrm{~m}$ between sample no. $12 \mathrm{~B}$ of zone 3 and no. 1 of zone 2 .

As there was not room for all the samples of zone 2 in the range chart of fig. $4 a$, a detail of the upper part of the boring has been constructed and presented as fig. 5 .

Zone 2 reflects Arctic to High-Arctic conditions. Elphidium excavatum clavata dominates the assemblages $(49 \%$ to $74 \%$ and Cassidulina reniforme is subdominant ( $20 \%$ to $13 \%)$. Common accessory species are Nonion orbiculare, N. labradoricum, Elphidium asklundi and Astrononion gallowayi. Stainforthia loeblichi (Feyling-Hanssen), Islandiella norcrossi and Buccella frigida are constantly present.

The increasing faunal dominance may indicate increasing environmental stress upwards through the zone. The rich foraminiferal content of the upper samples may support this. It could be caused by a low sedimentation rate in a high-arctic, frozen, environment with little influx of sediment-loaded melt-water.

The boreal element is less than $3 \%$ in most of the samples. Only in sample $10 \mathrm{~B}$ at $9.4 \mathrm{~m}$, is it as high as $6 \%$. Bulimina gibba/marginata occurs in this sample, and Elphidium albiumbilicatum attains $4 \%$. A high number of different species (49) and a high diversity (15) is found in sample $8 \mathrm{~B}$ at $7.4 \mathrm{~m}$. Thus, a sligth amelioration may have occurred between $10 \mathrm{~m}$ and $7 \mathrm{~m}$ below sea floor.

Planktonic specimens are practically absent in zone 2. The content of shallow-water species, such as Nonion orbiculare, Elphidium albiumbilicatum, E. asklundi, E. bartletti Cushman and $E$. subarcticum decreases upwards through the zone, indicating a transgression from sample 1 , at $14.7 \mathrm{~m}$. This transgression was temporarily interrupted in sample $10 \mathrm{~B}$, at $9.4 \mathrm{~m}$, and again in $7 \mathrm{CA}$, at $6.5 \mathrm{~m}$. The shallow-water species Nonion orbiculare is frequent in sample $10 \mathrm{~B}$ and $\mathrm{El}$ phidium subarcticum in 7CA.

Zone 2 represents an ice age, and its upper part was deposited during a pronounced stadial of this ice age.

Shell fragments of molluscs occurred in some of the samples of zone 2: Hiatella arctica (Linné) and Macoma calcarea (Chemnitz) at $14.7 \mathrm{~m}$, Portlandia arctica (Gray) and Nuculana pernula (Müller) at $10.4 \mathrm{~m}, N$. pernula, Yoldiella lenticula (Müller), Macoma calcarea and Astarte elliptica Brown) at $9.4 \mathrm{~m}$., again Portlandia arctica and Yoldiella lenticula at $6.5 \mathrm{~m}$, and $P$. arctica, $Y$. lenticula and Nucula tenuis (Montagu) at $3.2 \mathrm{~m}$.

These species provide additional evidence of arctic sea temperatures, and the occurrence of Hiatella arctica, Macoma calcarea and Astarte elliptica in the lower part of the zone is commensurate with the foraminiferal data in suggesting 
Table 10, Zone 1

Sample no. 1A, depth $0.0 \mathrm{~m}$, weight $200 \mathrm{~g}$

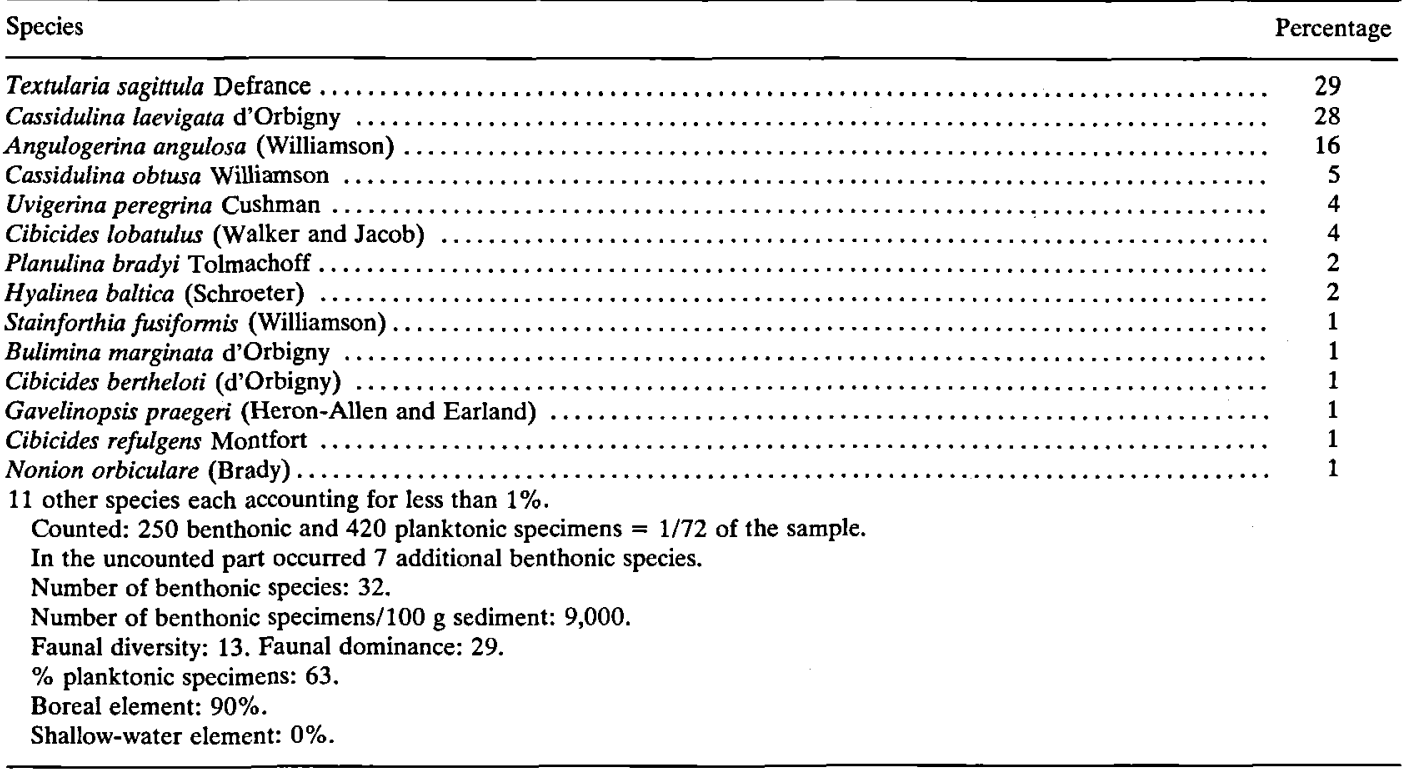

shallower water conditions in the earlier part of zone 2 .

Zone 1 (Table 10) is represented only by the top sample, no. $1 \mathrm{~A}$, from the sea floor. Its benthonic assemblage contains $90 \%$ boreal specimens of species such as Textularia sagittula Defrance, Cassidulina laevigata, Angulogerina angulosa, and arctic or arctic-boreal species are almost absent. Characteristically there is a frequent occurrence of planktonic species, mostly Globigerina pachyderma and Globigerina bulloides d'Orbigny. They account for $63 \%$ of the total foraminiferal assemblage.

The assemblage of sample 1A demonstrates environmental conditions - temperature, salinity, depth - as of the present day at the bore site (cf. Jarke, 1961). There is a low faunal dominance, quite a high faunal diversity and no shallow-water specimens. The total number of foraminifera per $100 \mathrm{~g}$ sediment is high at 24,000 benthonic and planktonic specimens combined. This infers very slow or no sedimentation in the area.

\section{Correlation and age}

An attempt is made in the following section to correlate the microbiostratigraphical units of the present borehole with those already constructed for Borehole 2501 in the Statfjord C Field, approximately $11 \mathrm{~km}$ to the NNE of the present borehole (cf. Feyling-Hanssen, 1981). In doing so it should be kept in mind that the geological record of a North Sea boring such as the present one may not be complete. Uncomformities may occur at several levels and gaps in sampling leave parts of the sequence unrepresented. This may lead to misinterpretation and miscorrelation even over small distances.

Borehole 2501 in the Statfjord C Field was subdivided into 8 microbiostratigraphical units from $R$, youngest, to $Y$, oldest. Zone $W$, at $45 \mathrm{~m}$ to $56 \mathrm{~m}$ below sea floor, of that boring reflects an interglacial stage which was named the Statfjord Interglacial. It was correlated with the Eemian of northwestern Europe, and thus with Oxygen isotope Stage 5e of Emiliani (1955; cf. also Shackleton and Opdyke, 1973; Kellogg et al., 1978).

\section{The Flandrian}

Zone 1 of the present boring, i.e., the uppermost sample of borehole 3506 correlates with zone $R$ of boring 2501, which was also represented by the topmost sample. The benthonic assemblage 


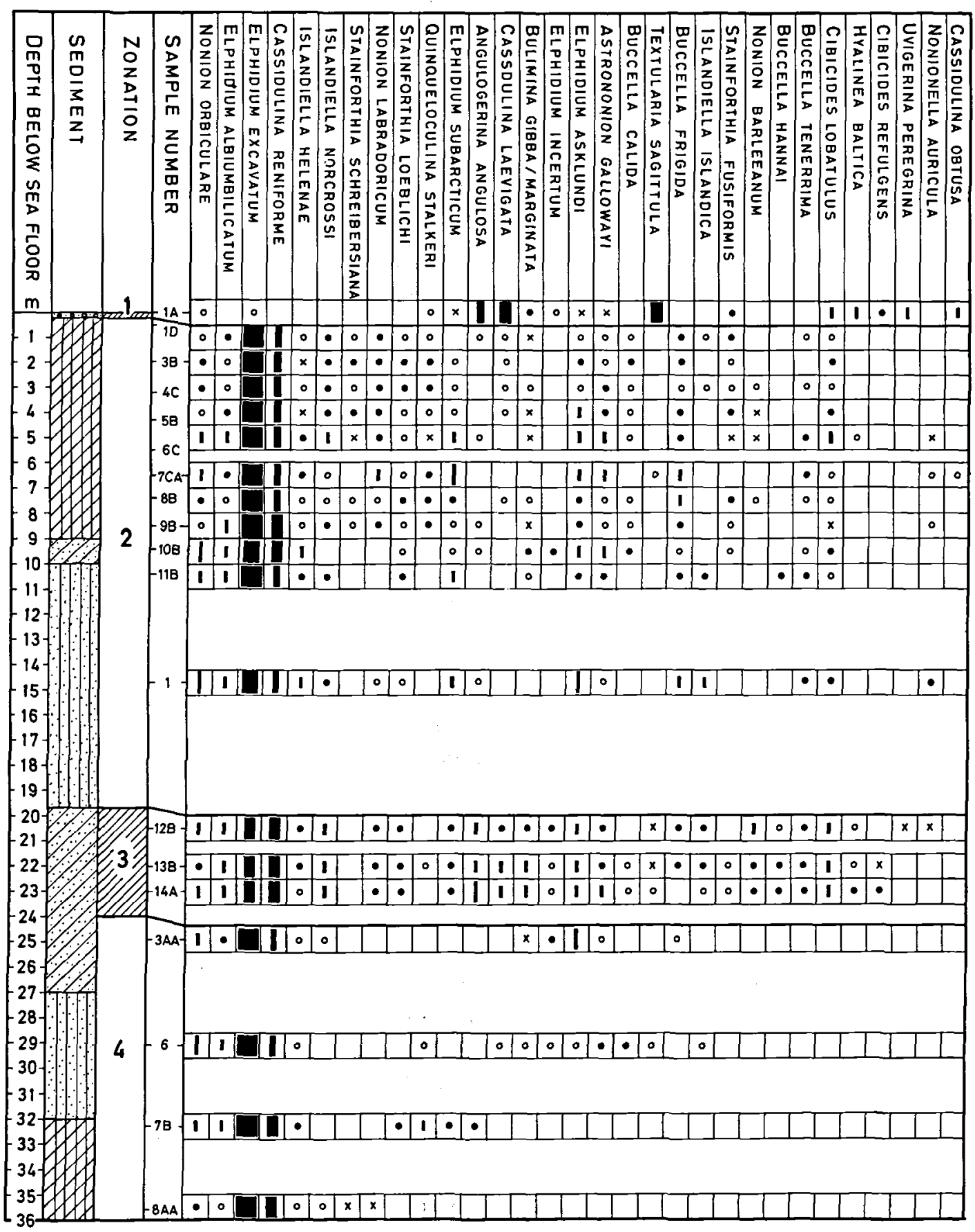

Fig. 5. Detailed range chart for the upper part of Borehole 3506. 
of both samples contained $90 \%$ Boreal specimens, among them frequent Angulogerina angulosa and Cassidulina laevigata. Planktonic foraminifera accounted for more than $60 \%$ of the total foraminiferal assemblage, benthonic plus planktonic. The number of different benthonic species was 32 in both samples. Textularia sagittula was more important in zone 1 and Cibicides refulgens in zone $\mathrm{R}$. The number of foraminifera per $100 \mathrm{~g}$ sediment was three times that of zone 1 in zone $\mathbf{R}$.

Our present interglacial, the Flandrian or the Holocene, which covers approximately 10,000 years, is thus represented by less than $20 \mathrm{~cm}$ of gravelly to silty sand (cf. sediment record p. 32). Immediately below this occurs stiff, silty clay with foraminifera of high-arctic habitat. In Borehole 2501 in the Statfjord C Field the Flandrian is also represented only by a few centimetres of sand. Such poor representation of the Flandrian is known also from other North Sea boreholes (e.g., Holmes, 1977; Jansen and Hensey, 1981; Skinner and Gregory, in press.). One may suspect earlier interglacials of the Quaternary to be equally poorly represented. Their sediments may therefore wholly or partly escape sampling in many North Sea boreholes. Thicker Flandrian deposits are known, however, and also deposits with assemblages of transitional character, between arctic and boreal environments (cf. Moyes et al., 1974; Nagy and Ofstad, 1980).

Zone 1 is probably of Recent or nearly Recent age, very late Flandrian or very late Oxygen isotope stage 1 .

\section{The Statfjord Interglacial}

Zone 3 of the present boring correlates with the upper part of zone $W$ of boring 2501 in the Statfjord C Field, i.e., with the end of the Statfjord Interglacial.

Except for the top zone with its Recent assemblage, zone 3 is the only unit of the present boring with a considerable amount of planktonic foraminifera, $25-17 \%$. Sample $7 \mathrm{~B}$ at $32.3 \mathrm{~m}$ contained $7 \%$ planktonic specimens. In all the other investigated samples of the boring this percentage is (often considerably) less than 5 .

In boring 2501 of Statfjord $C$ the only unit, outside zone $\mathrm{R}$, with a considerable amount of planktonic foraminifera is zone $\mathrm{W}$ and also the lower half of zone $\mathrm{V}$. The maximum content in zone W was $21 \%$ (sample $23 \mathrm{a}$ at $52 \mathrm{~m}$ ). Sample $23 \mathrm{~b}$, just above, had also $21 \%$, sample 22 , at 48 $\mathrm{m}$, contained $16 \%$, whereas in the lower sample of the overlying zone $\mathrm{V}$ only $10 \%$ of the total assemblage was made up of planktonic specimens. The curve of planktonic percentages of zone 3 of boring 3506 thus seems to conform with the fall off of planktonic frequencies in zone $W$ of boring 2501. Also the very high number of different benthonic species per sample correlate in the two zones.

But optimal interglacial conditions are not reflected by the assemblages of zone 3 . The content of boreal foraminifera amounts to $20 \%$ whereas in zone $W$ of boring 2501 it reached $74 \%$.

Sanders (1960) introduced a simple method of comparing faunas. The lowest percentages for each species common to the two assemblages which are compared, are summed. This sum is the similarity index. A high value of this index shows a high degree of similarity, whereas a low value indicates little similarity. When the samples of zone 3 are in this way compared with the assemblages of zone $\mathrm{W}$ and $\mathrm{V}$ of boring 2501 , the highest indices are found with sample 23a (84-86) and sample 22 (81-83) within zone W. When compared with the most ameliorated assemblage of zone $\mathrm{W}$, with a boreal element of $74 \%$, the similarity is only $28-40$, because the optimal part of the interglacial is not represented in zone 3 . When the zone 3 assemblages are compared with the two assemblages of zone $\mathrm{V}$ of boring 2501 , the similarity indices are $73-79$ and 75-77.

The closest correlation of zone 3 of boring 3506 in the Statfjord B Field is thus with the late part of zone W of boring 2501 in the Statfjord C Field, i.e., zone 3 represents the end of the Statfjord Interglacial.

This interglacial most probably correlates with Oxygen isotope stage 5e (cf. e.g., Shackleton and Opdyke, 1973; Kellogg et al., 1978) and with the Eemian of northwestern Europe (Feyling-Hanssen, 1981; Mangerud et al., 1979).

From the Tartan Field farther south in the North Sea $\left(58^{\circ} 22^{\prime} \mathrm{N}, 0^{\circ} 4^{\prime} \mathrm{E}\right)$. Jansen and Hensey (1981) describe a foraminiferal zone $\mathrm{V}$, at 25-38 $\mathrm{m}$ below sea floor, $17 \%$ of which is made up of planktonic specimens of which $12 \%$ are Orbulina 
universa d'Orbigny. This zone is supposed to represent an interglacial "probably Eemian or older".

Skinner and Gregory (in press) correlate the upper part of an amelioration attributed to the Eemian of their I.G.S. Borehole $78 / 9$ with the Statfjord Interglacial of Borehole 2501 in the Statfjord C Field. Their site is at Lat. $61^{\circ} 30.65^{\prime} \mathrm{N}$; Long $0^{\circ} 49.78^{\prime} \mathrm{E}$ in $191 \mathrm{~m}$ of water and the upper leaf of their Eemian is $20 \mathrm{~m}$ below sea floor.

They found relatively high percentages of planktonic specimens and quite large numbers of southern benthonic specimens. Two paleomagnetic reversals, interpreted as the "Blake Paleomagnetic Event" occurred in these samples. This event is attributed to the Eemian Interglacial and thus supports the foraminiferal data.

Zone 3 is comparable also to an ameliorated assemblage described by Lord (1980) from $16 \mathrm{~m}$ below sea floor of the Esso-Shell borehole A 4-2 in the South Cormorant Field. Gregory (in Skinner and Gregory, in press) noted the affinity of this assemblage with the top leaf of her Eemian assemblages in the above mentioned I.G.S. Borehole $78 / 9$, and the present author, kindly afforded by Dr. Alan Lord, had the opportunity to examine the $16 \mathrm{~m}$ assemblage of borehole A 4-2 and can confirm its very close resemblance to the Statfjord Interglacial assemblage of sample 23b at $52 \mathrm{~m}$ of boring 2501 in the Statfjord C Field.

\section{Pre Eemian amelioration}

Zone 7 of the present boring correlates with zone Y of Borehole 2501 in the Statfjord C Field. Both units are characterized by the frequent occurrence of Nonion orbiculare and a firm representation of Cassidulina teretis. Bulimina gib$\mathrm{ba} /$ marginata is quite common and so is $\mathrm{El}$ phidium albiumbilicatum. These zones represent a firm amelioration in the climatic development of the Statfjord area.

The underlying zone 8 of the present borehole reflects a cold spell, represented only by one sample (19A), whereas zone 9 is again distinctly ameliorated. Correlatives of zone 8 and 9 are not represented in boring 2501, which terminated in zone $\mathrm{Y}$.

This mild interval, zone 7 and zone $Y$, is in both borings separated from the Eemian (5e) amelioration by an interval with high-arctic foraminiferal assemblages reflecting severe ice age conditions. We thus have indication of an ameliorated period prior to the Eemian and before at least one full glacial period (or the sedimentary record may not be complete). Zone 7-9 and zone $Y$ could belong in an early part of the Pleistocene. Cassidulina teretis and scattered specimens of Elphidiella hannai and even of Cibicides grossa occur in zone 7 and these species are known mainly from the Lower Pleistocene and Upper Tertiary (Feyling-Hanssen, 1980). However, the two latter species are most probably reworked, and Cassidulina teretis does occur also in younger parts of the Pleistocene - even in Recent deposits (Feyling-Hanssen, 1980).

It would seem tempting to correlate this warmer interval with a classical pre Eemian interglacial such as the Holsteinian of Northwest Europe. But it is the impression at the author that the amelioration was not strong enough for such a comparison. The percentages of boreal specimens in zone 7-9 and zone $\mathrm{Y}$ are never as large as in zone 3 and zone $W$ and come nowhere near the levels of the present day, zone 1 and zone $R$. There is further no rise in the content of planktonic specimens. Conversly, the percentage of shallow-water specimens stays remarkably high.

Correlation with one or more of the numerous Northwest European on-shore findings and units in this part of the Quaternary history will probably have to wait until more is known of the North Sea history. A comparison with the deep sea oxygen isotope stratigraphy should, however, be possible.

The isotope record shows (e.g., Shackleton and Opdyke, 1973, p. 48) that the peaks of stage 7 do not reach the level of stage $5 \mathrm{e}$. Even the record of stage 1 (the Holocene) protrudes above those of stage 7 . Only a moderate rise in sea level occurred during stage 7 (1.c., p.50). Thus the amelioration did not reach such interglacial levels as it did in both stage 5e and stage 1.

A smilar picture is revealed by the charts and diagrams of the two Statfjord borings. It is suggested that zone 7 of boring 3506 and zone $Y$ of boring 2501 correlate with oxygen isotope stage 7.

Stage 7 is sharply broken by a low reading in its 
middle part "apparently by a substantial ice accumulation" (Shackleton and Opdyke, 1973, p.50). This is registered in many deep sea cores, e.g., also in V28-56 in the Norwegian Sea (Kellogg et al., 1978). It might well be that the cold spell reflected by zone 8 compares with the break in stage 7, and that zone 9 correlates with the earlier part of oxygen isotope stage 7 . In this case zone 9 should be approximately 250,000 years old - if not a hiatus occurs between zone 7 and zone 6 .

Ice age layers

More than one half of the present boring was deposited during ice ages.

Zone 4 and zone 6 which in the present borehole is situated between the ameliorated zone 7 and the ameliorated zone 3 correlates with zone X which in Borehole 2501 in the Statfjord C Field separates the ameliorated zone $Y$ from the Statfjord Interglacial, zone W. A warmer interval corrresponding to zone 5 of the present borehole, is not found in zone $\mathrm{X}$ of Statfjord $\mathrm{C}$.

Similarity indices are as high as $80-90 \%$ between zone 4 of the Statfjord B boring and the upper part (nos. 25-28) of zone $X$ of the Statfjord $\mathrm{C}$ boring. They are again high between zone 6 of Statfjord B and the lower part (nos. $29-30)$ of zone X of Statfjord C (81-83\%). Either an unconformity occurred at $66-67 \mathrm{~m}$ below sea floor in boring 2501 - or the level of an amelioration corresponding to zone 5 was not sampled in that borehole.

If the correlation with the deep sea oxygen isotope stages outlined above, is accepted, the high-arctic zones 4 and 6 of the present boring and likewise the high-arctic zone $\mathrm{X}$ of boring 2501 in the Statfjord C Field would correlate with the glacial oxygen isotope stage $6-$ if this part of the North Sea was at all covered by sea during that very cold period.

The oxygen isotopic record of core V28-238 (Shackleton and Opdyke, 1973, fig. 9) shows an ameliorated oscillation in the lower middle part of stage 6. It could form a pleasant counterpart to the ameliorated spell of zone 5 of the present borehole. This oscillation does not show up in the oxygen isotope diagram of core V28-56 in the Norwegian Sea (Kellogg et al., 197,8).
Compared with classical units, zones 4 and 6 of boring 3506 and zone $X$ of 2501 represent parts of the complex Saalian, and zone 5 could belong to an interstadial during that period.

Zone 2 of the present borehole has more in common with zone $U$ of boreholde 2501 in the Statfjord C Field than with zone T. These units were both considered to be of Weichselian age, zone $U$ representing an early cold phase and zone $\mathrm{T}$ a middle part, on a general scale stretching from approximately $50,000 \mathrm{BP}$ to $25,000 \mathrm{BP}$ (Feyling-Hanssen 1981). Interpreted this way, zone $\mathrm{T}$ includes the șightly ameliorated middle Weichselian Sandnes Interstadial (FeylingHanssen, 1971; 1974).

The quite high frequencis of Islandiella norcrossi and Nonion labradoricum, characteristic of zone $\mathrm{T}$ are not found with assemblages of zone 2 of the present boring. The percentage of boreal specimens is also generally lower in zone 2 than in zone $\mathrm{T}$, proportions reaching $5 \%$ only in one sample. The very low content of planktonic foraminifera and the high faunal dominance is, on the other hand, found in zone $U$ of the Statfjord $\mathrm{C}$ boring.

If this is the case, zone 2 would be Lower Weichselian in age and the Middle and Upper Weichselian would be lacking in the present borehole. Zone 2 would then correlate with oxygen isotope stage 4 . The high content of shallow-water specimens, particularly in the lower parts of zone 2, does not, however, occur in zone $\mathrm{U}$ of boring 2501 .

Another possibility is that zone 2 is younger. It may be that the lower part of zone 2 reaches back into zone $T$ of 2501 and that its upper, particularly the upper three samples of the zone, with an extremely high dominance of Elphidium excavatum clavata, continues into the very cold main Weichselian. This part would then correlate with the very thin zone $S$ af boring 2501 .

Compared with the oxygen isotop stages, the lower part of zone 2 would thus belong in a late part of stage 3 whereas its upper part, approximately from $4.0 \mathrm{~m}$ to $0.25 \mathrm{~m}$ below sea floor, would belong to stage 2 .

In this part of the core we are probably within the reach of $\mathrm{C}^{14}$ dating and guidance may be found that way. 


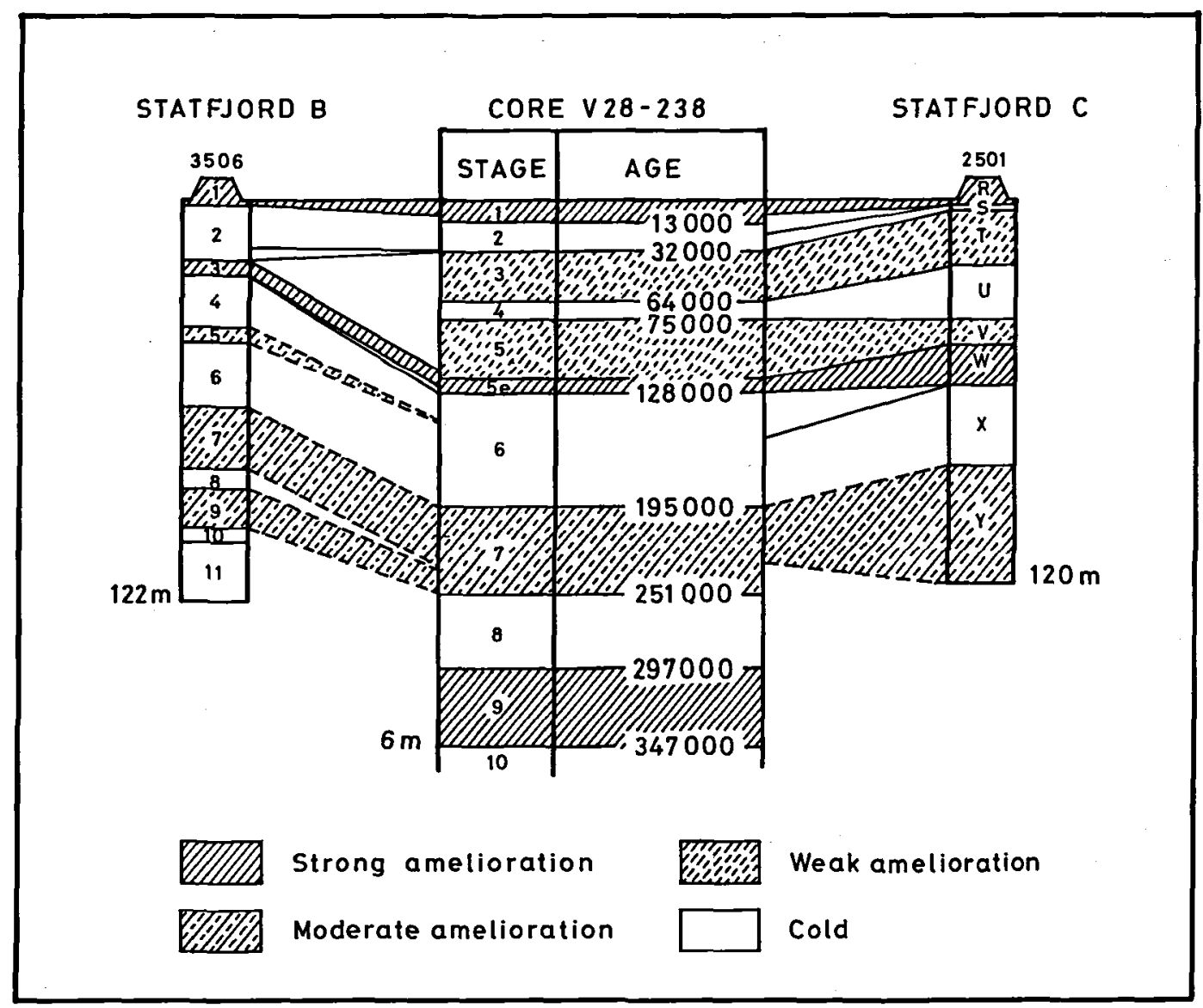

Fig. 6. Correlation between the biostratigraphical units of Borehole 3506 in the Statfjord B Field and the biostratigraphical units of Borehole 2501 in the Statfjord C Field (Feyling-Hanssen, 1981), and tentative correlation of these units with the oxygen isotope stages and ages of the Pacific core V28-238, redrawn from Shackleton and Opdyke, 1973.

The non-marine deposit

Zone 11 , with no, or only reworked, foraminifera, is supposed to represent non-marine delta deposits, maybe of an infilled channel. Seismic investigations seem to indicate the presence of a channel in the lower part of boring 3506 (written communication, Tor Løken, 1979, cf. Sissons, 1981). This part of the boring may thus have been deposited during a significantly low sea level, which might have occurred during the extremely cold oxygen isotope stage 8 (Shackleton and Opdyke, 1973). The infilling of such a channel could have taken place towards the end of the cold period with rising sea level - which lead into the marine environment reflected in zone 10.

Attempts at correlating the units of the present boring with those of other borings in the Quaternary of the North Sea (e.g. Løfaldli, 1973; Løken, 1976; Holmes, 1977; Hughes et al., 1977; Gregory and Harland, 1978; Harland et al., 1978; Bue and Løken, 1979; Feyling-Hanssen, 1979; Nagy and Ofstad, 1980) have not been made. Too many details about the foraminiferal assemblages are lacking.

Acknowledgments. The author is grateful to Tor Loken of the Norwegian Geotechnical Institute, Oslo, for placing the samples at his disposal and for generous information and advise concerning the material. He extends his thanks to Karen Luise Knudsen, Department of Micropaleontology, Geological Institute, University of Aarhus, who critically read the manuscript, to Aage Bach Sørensen, Prakla-Seismos, Hannover, for valuable suggestions, and to David N. Penney, University of Dublin, who kindly improved the English of the text. Thanks is 
also due to S. Meldgaard, Department of Micropaleontology, Aarhus University for laboratory processing of the samples, Jette Gissel Nielsen for making the drawings, and Lissi Østerhaab Mogensen for kindly arranging the manuscript. Permission to publish geological information for the Statfjord Field from Mobil Exploration Norway Inc., Stavanger, on behalf of the Statfjord Group, is gratefully acknowledged.

\section{Dansk Sammendrag}

Uforstyrrede prøver fra den $122 \mathrm{~m}$ dybe boring 3506 i Statfjord B Feltet i den nordlige Nordsø indeholdt velbevarede og rige foraminifer-selskaber, hvorved det var muligt at inddele boringen i 11 biostratigrafiske enheder. De fleste af disse repræsenterer istidsforhold, nogle af stadial, nogle af interstadial karakter. Zone 3 (24,0-19,7 m under havbunden) repræsenterer slutningen af Statfjord Interglacialen, beskrevet fra en tidligere undersøgt boring, 2501, i Statfjord C Feltet, og således slutningen af Eem Interglacialen. Boringens zoner er forsøgt korreleret med tidligere etablerede ilt isotop stadier $i$ dybhavskerner. Således er zone $9 \operatorname{og} 7$, som indeholder en del varmekrævende foraminifer-faunaer, og den mellemliggende zone 8, forsøgsvis korreleret med ilt isotop stadie 7 . Hvis dette er rigtigt, skulle boringens zone 9 være omtrent 250.000 år gammel. Den nederste del af boringen, zone 11 , synes at bestå af non-marine deltaaflejringer.

\section{References}

Bue, B., and Løken, T. 1979: Geology of the Quaternary sediments from the Frigg Field. Norw. Geotech Inst., Report $520023-1,1-16+1-12$.

Emiliani, C. 1955: Pleistocene temperatures. Journ. of Geol., $63,538-578$.

Feyling-Hanssen, R. W. 1955: Stratigraphy of the marine Late Pleistocene of Billefjorden, Vestspitsbergen. Norsk Polarinst. Skr. 107, 1-186.

Feyling-Hanssen, R. W. 1964: Foraminifera in Late Quaternary deposits from the Oslofjord area. Norges Geol. Unders. 225, 1-383.

Feyling-Hanssen, R. W. 1971: Weichselian interstadial Foraminifera from the Sandnes-Jæren area. In: Feyling-Hanssen, R. W.; Jørgensen, J. A., Knudsen, K. L., and Andersen, A.-L. L. Bull. geol. Denmark 21 (2-3), 72-116.

Feyling-Hanssen, R. W. 1972: The foraminifer Elphidium excavatum (Terquem) and its variant forms. Micropaleontology, 18, 337-354.

Feyling-Hanssen, R. W. 1974: The Weichselian section of Foss-Eigeland, Southwestern Norway. Geol. Fören. Stockholm Förh. 96, 341-353.
Feyling-Hanssen, R. W. 1979: Micropaleontological investigation of soil samples from borings B8-B and B9-C, Frigg Field, North Sea. In: Bue, B. and Loken, L. Norw. Geotech. Inst. Report 520023-1, Appendix, 1-12.

Feyling-Hanssen, R. W. 1980: Microbiostratigraphy of young Cenozoic marine deposits of the Qivituq Peninsula, Baffin Island. Marine Micropaleontology, 5, 153-184.

Feyling-Hanssen, R. W. 1981: Foraminiferal indication of Eemian interglacial in the northern North Sea. Bull. geol. Soc. Denmark 29 (4), 175-189.

Feyling-Hanssen, R. W. in press: Quantitative methods in micropaleontology. Spec. NDP Publ. 2, Stavanger.

Feyling-Hanssen, R. W. and Buzas, M. A. 1976: Emendation of Cassidulina and Islandiella helenae n.sp.J. foram. Res. 6 (2), 154-158.

Feyling-Hanssen, R. W., Jørgensen, J. A., Knudsen, K. L. and Andersen, A.-L. L. 1971: Late Quaternary Foraminifera from Vendsyssel, Denmark and Sandnes, Norway. Bull. geol. Soc. Denmark 21 (2-3), 67-317.

Gregory, D. M. and Harland, R. 1978: The late Quaternary climatostratigraphy of IGS Borehole SLN 75/33 and its application to the paleoceanography of the north-central North Sea. Scott. Jour. Geol. 14 (2), 147-155.

Harland, R., Gregory, D. M., Hughes, M. J. and Wilkinson, J. P. 1978: A late Quaternary bio- and climatostratigraphy for marine sediments in the north-central part of the North Sea. Boreas 7 (2), 91-96.

Holmes, R. 1977: Quaternary deposits of the central North Sea, 5. The Quaternary geology of the U.K. sector of the North Sea between $56^{\circ}$ and $58^{\circ}$ N. Inst. Geol. Sci. Rep. $77 / 14,1-50$.

Hughes, M. J. Gregory, D. M., Harland, R. and Wilkinson, I. P. 1977: Late Quaternary foraminifera and dinoflagellate cysts from boreholes in the U.K. sector of the North Sea between $56^{\circ} \mathrm{N}$ and $58^{\circ} \mathrm{N}$. In: Holmes, R. Inst. Geol. Sci. Rep. 77/14, 36-46.

Jansen, J. H. F., Doppert, J. W. C., Hoogendorn-Toering, K., De Jong, J., and Spaink, G. 1979: Late Pleistocene and Holocene deposits in the Witch and Fladen Ground area, northern North Sea. Nederlands Jour. Sea Research 13 (1), 1-39.

Jansen, F. J. H. and Hensey, A. M. 1981: Interglacial and Holocene sedimentation in the northern North Sea: an example of Eemian deposits in the Tartan Field. Spec. Publs. int. Ass. Sediment 5, 323-334.

Jarke, J. 1961: Die Beziehungen zwischen hydrographischen Verhältnissen, Faziesentwicklung und Foraminiferenverbreitung in der Nordsee als Vorbild für die Verhältnisse während der Miocän-Zeit. Meyniana 10, 21-26.

Kellogg, T. B., Duplessy, J. C. and Shackleton, N. J. 1978: Planktonic foraminiferal and oxygen isotopic stratigraphy and paleoclimatology of Norwegian Sea deep-sea cores Boreas 7, 61-73.

Lord, A. 1980: Interpretation of the Lateglacial marine environment of NW Europe by means of Foraminiferida. In: Lowe, J. J., Gray, J. M., Robinson, R. E. Studies in the Lateglacial of North-West Europe. Pergamon Press, Oxford, 103-114.

Løfaldli, M. 1973: Foraminiferal biostratigraphy of Late Quaternary deposits from the Frigg Field and Booster Station. NTNF's Kontinentalsokkelkontor Publ. 18, Oslo, 1-82.

Løken, T. 1976: Geology of superficial sediments in the Northern North Sea. Proc. Intern. Conf. on the Behaviour of off-shore Structures, BOSS'76, 1, 501-515. Also in Norw. Geotech. Inst. Publ. 114, 45-59.

Mangerud, J., Sønstegaard, E. and Sejrup, H.-P. 1979: Correlation of the Eemian (interglacial) stage and the deep-sea oxygen-isotope stratigraphy. Nature 277, 189-192.

Moyes, J., Gayet, J., Pujol, C. and Pujos-Lamy, A. 1974: Etude 
stratigraphique et sédimentologique: CEPM-CNEXO, Orgon 1. Mer de Norwège, Aout 1974, 81-137.

Nagy, J. and Ofstad K. 1980: Quaternary foraminifera and sediments in the Norwegian Channel. Boreas 9, 39-52.

Sanders, H. L. 1960: Benthic studies in Buzzards Bay. III. The structure of the soft-bottom community. Limnol. Oceanogr. 5 (2), 138-153.

Shackleton, N. J. and Opdyke, N. D. 1973: Oxygen Isotope and palaeomagnetic stratigraphy of Equatorial Pacific Core V28-238: Oxygen Isotope temperatures and Ice volumes on a $10^{5}$ year and $10^{6}$ year scale. Quaternary Research 3, 39-55.
Sissons, J. B. 1981: The last Scottish ice-sheet: facts and speculative discussion. Boreas 10, 1-17.

Skinner, A. and Gregory, D. M. in press: Quaternary Geology and Foraminifera of I.G.S. Borehole $78 / 9$ in the northern North Sea.

Walton, W. R. 1964: Recent foraminiferal ecology and paleo-ecology, 151-237. In: Imbrie, J. and Newell, N. D. (editors): Approaches to paleoecology. Wiley and Sons, New York.

Wiegank, F. 1979: Palaeomagnetic dating and correlation of Quaternary deposits in the GDR. IGCP Project No. 73-1-24 Quaternary Glaciations in the Northern Hemisphere, Report No. 5, 254-262. 